\title{
MANAGERIAL ABILITY OF LIME GROWERS ABOUT RECOMMENDED CULTIVATION OF LIME IN RAJASTHAN
}

\author{
ALOK KUMAR ${ }^{1}$, VIKASH PAWARIYA ${ }^{2} \&$ RAVINDRA SINGH ${ }^{3}$ \\ ${ }^{1}$ Research Scholar, Department of Extension Education, S. K. N. College of Agriculture, Jobner Rajasthan, India \\ ${ }^{2}$ Research Scholar, Department of Agricultural Economics, S. K. N. College of Agriculture, Jobner-Rajasthan, India \\ ${ }^{3}$ Co-ordinator, PDDUUKSY, Education Division, KAB, ICAR, New Delhi, India
}

\begin{abstract}
Management is the process by which the farmer is able to enhance return from the farm on a sustained basis for the attainment of family goal, while the lime is grown mainly for market purpose. The economic return is the prime concern of the farmers. The improved lime production technologies recommended by the research institutions ensure high yield and good return to the farmers.

KEYWORDS: Farmer, Family Goal, Market Purpose, High Yield and Good Return
\end{abstract}

Received: Jan 13, 2017; Accepted: Feb 21, 2017; Published: Feb 24, 2017; Paper Id.: IJASRAPR201722

\section{INTRODUCTION}

Every enterprise is basically interested in maximization of its profit as profit usually is taken as a measure of welfare or utility. How far the farmers growing lime in the zone (IIIb) are successful in fulfilling these objectives is the test required to be done as we are interested to increase the profitability of lime growers of Rajasthan in general and zone (IIIb) in particular.

It is generally observed that the lime growers are not well educated and posses less knowledge. Similarly, they have the experience of lime growing but do not know scientific management of lime orchard. Thus, neither they have higher knowledge nor they have an experience of management of lime orchard, even though they carry out good production. India, being the second largest producer of fruits occupies a very good prestigious position in the world. Therefore, good management of lime orchard is most essential for development of Indian horticulture. The cultivation of lime enterprise mainly depends on this management role played by the lime growers.

Moreover, the lime growers perform many functions in carrying out better production such as, preparing a plan of work, giving clear instructions integrating the work, taking proper decision at the right time, implementing decision etc, in carrying out the management activity in lime orchard. All above functions are involved in one or the other way, many management components viz planning, organizing, directing, controlling, human relation, leading, coordinating and decision making. Keeping all these views in mind the present investigation entitled "Managerial ability of lime growers about recommended cultivation of lime in Flood Prone Zone (IIIb) of Rajasthan" was under taken. 


\section{METHODOLOGY}

The Rajasthan state has ten agro-climatic zones, out of which flood prone eastern plain zone (IIIb) was selected purposely for the study purpose because this zone has maximum production under lime cultivation. This zone consist five districts, out of which Bharatpur and Karuli districts were selected because these districts has maximum production of lime. Bharatpur and Karauli districts have 9 and 5 panchayat same ties, respectively, out of which two panchayat same ties of Bharatpur i.e. Bayana and Weir and one panchayat samiti of Karauli i.e. Nadoti were selected because these panchayat samities occupied maximum area and production in their respective districts. Separate lists of all the lime growing villages, from each the selected panchayat sameti was prepared and 3 villages from each panchayat samiti were selected purposely due to having maximum number of lime growers. From the selected villages, a comprehensive list of all lime growers having at least one bigha orchard for last five years were prepared and 30 per cent of lime growers from each of the village and total 200 lime growers from all 9 villages were selected sample with the help of random sampling technique for the study purpose.

In order to measure the managerial ability of lime growers, the scale developed by Jadav and Popat (2004) was used with slight modifications. The data were collected for by personally interviewing the respondents and were classified, tabulated and statistically analysed, which led to following findings.

\section{FINDINGS}

In order to measure the managerial ability of lime growers about recommended cultivation of lime the schedule developed administered to each lime grower. The complete response was received from each lime grower and the managerial ability index calculated. The final managerial ability index was determined by averaging the index form the respective lime growers. The classification of respondents based on their managerial ability index is presented in Table 1.

Table 1: Distribution of Lime Growers According to Their Managerial Ability About Recommended Cultivation of Lime $\mathbf{N}=\mathbf{2 0 0}$

\begin{tabular}{|c|l|c|c|}
\hline S. No. & \multicolumn{1}{|c|}{ Category } & Frequency & Percentage \\
\hline 1. & $\begin{array}{l}\text { Low managerial ability (below 48.46 } \\
\text { score) }\end{array}$ & 43 & 21.50 \\
\hline 2. & $\begin{array}{l}\text { Medium managerial ability (from 48.46 to } \\
\text { 69.74 score) }\end{array}$ & 123 & 61.50 \\
\hline 3. & $\begin{array}{l}\text { High managerial ability (above 69.74 } \\
\text { score) }\end{array}$ & 34 & 17.00 \\
\hline & Total & $\mathbf{2 0 0}$ & $\mathbf{1 0 0}$ \\
\hline & Mean $=\mathbf{5 9 . 1 0}$ score & \multicolumn{2}{|c|}{ S.D. $=\mathbf{1 0 . 6 4}$ score } \\
\hline
\end{tabular}

It can be seen from the Table 1 that majority of respondents (61.50 per cent) were observed in the medium managerial ability category, while 21.50 per cent respondents fell under the category of low managerial ability. The remaining 17.00 per cent respondents possessed high managerial ability. Thus, the managerial ability of the respondents was predominantly medium.

Hence it can be concluded from the above findings that the managerial ability of lime growers about recommended cultivation of lime orchard was medium.

This might be due to the medium education level of lime growers. Further, about two-third respondents had medium level of attitude towards modern agriculture resulting into medium level of managerial ability. 
Further the managerial ability of the lime growers in different indicators of managerial ability of the lime growers were also analysed separately and presented as follows:

\section{Knowledge}

It is quite clear from the Table 2 that 73.50 per cent respondents possessed medium knowledge while 12.50 and 14.0 per cent lime growers fell under low and high knowledge, respectively.

Table 2: Distribution of Lime Growers According to Their Knowledge

About Recommended Cultivation of Lime $\mathbf{N}=\mathbf{2 0 0}$

\begin{tabular}{|c|l|c|c|}
\hline S. No. & \multicolumn{1}{|c|}{ Category } & Frequency & Percent \\
\hline 1. & Low (Below 19.93 score) & 25 & 12.50 \\
\hline 2. & Medium (from 19.93 to 23.79 score) & 147 & 73.50 \\
\hline 3. & High (Above 23.79 score) & 28 & 14.00 \\
\hline & Total & $\mathbf{2 0 0}$ & $\mathbf{1 0 0}$ \\
\hline & Mean=17.86 Score & S.D. $=5.93$ Score \\
\hline
\end{tabular}

Hence it can be concluded that near about two-third lime growers had medium knowledge. The probable reason for this finding might be that the lime growers might be benefited from the existing government fruits plant nursery situated in the study area. Hence, majority of lime growers were in regular contract with extension personnel, who might have helped them to acquire knowledge about recommended cultivation of lime due to which they might have managed their lime orchards more efficiently resulting in increase in their confidence which ultimately increased their managerial ability.

\section{Planning Ability of Lime Growers}

The data presented in Table 3 indicated that 55.00 per cent of respondents were having medium planning ability, whereas 27.00 and 18.00 per cent of them had low and high planning ability, respectively.

Table 3: Distribution of Lime Growers According to Their Planning Ability About Recommended Cultivation of Lime $\mathbf{N}=\mathbf{2 0 0}$

\begin{tabular}{|c|c|c|c|}
\hline S. No. & Category & Frequency & Percent \\
\hline 1. & Low (Below 10.49 score) & 54 & 27.00 \\
\hline 2. & Medium (from 10.49 to 20.33 score) & 110 & 55.00 \\
\hline 3. & High (Above 20.33 score) & 36 & 18.00 \\
\hline & Total & 200 & 100 \\
\hline & Mean $=15.41$ score & \multicolumn{2}{|c|}{ S.D. $=4.92$ score } \\
\hline
\end{tabular}

Hence, it can be concluded that about one half of respondents had possessed medium level planning ability about recommended cultivation of lime. This might be due to the reason that majority of the lime growers managed their orchards themselves as per their managerial skill that is not upto the mark but they might have remained in contact with the extension personnel who might have increased their planning ability resulting in overall medium planning ability.

\section{Organizing Ability}

It is apparent from this Table 4 that majority (62.50 per cent) of the respondents had medium level organizing ability, whereas 21.00 and 17.00 per cent of them had high and low organizing ability. It can be inferred that majority of the lime growers had medium level of organizing ability on their orchards. 
Table 4: Distribution of Lime Growers According to Their Organizing Ability About Recommended Cultivation of Lime $\mathbf{N}=200$

\begin{tabular}{|c|l|c|c|}
\hline S.No. & \multicolumn{1}{|c|}{ Category } & Frequency & Per cent \\
\hline 1. & Low (Below 3.18 score) & 33.00 & 16.50 \\
\hline 2. & Medium (from 3.18 to 5.90 score) & 12.50 & 62.50 \\
\hline 3. & High (Above 5.90 score) & 42.00 & 21.00 \\
\hline & Total & $\mathbf{2 0 0}$ & $\mathbf{1 0 0}$ \\
\hline & Mean = 4.54score & S.D.=1.36 score \\
\hline
\end{tabular}

This might be due to the reason that the organizing process includes identifying and grouping the work to be performed which the lime growers of the area used to perform at their orchards regularly with the help of family members or with the help contractors during fruiting season.

\section{Supervising Ability of Lime Growers}

Form the perusal of the data presented in Table 5 it is clear that 65.00 per cent of respondents had medium level of supervising ability, whereas, 21.00 and 14.00 per cent of then had low and high level of supervising ability. It can be concluded that majority of the lime growers had medium level of supervision ability of recommended cultivation of lime.

Table 5: Distribution of Lime Growers According to Their Supervising Ability About Recommended Cultivation of Lime $\mathbf{N}=\mathbf{2 0 0}$

\begin{tabular}{|c|l|c|c|}
\hline S.No. & \multicolumn{1}{|c|}{ Category } & Frequency & Percent \\
\hline 1. & Low (Below 10.46 score) & 42 & 21.00 \\
\hline 2. & Medium (from 10.46 to 21.32 score) & 130 & 65.00 \\
\hline 3. & High (Above 21.32 score) & 28 & 14.00 \\
\hline & Total & $\mathbf{2 0 0}$ & $\mathbf{1 0 0}$ \\
\hline & Mean = 15.89 score & \multicolumn{2}{|l}{ S.D. $=\mathbf{5 . 4 3}$ score } \\
\hline
\end{tabular}

This might be due to the reason that the supervision ability played important role in assessing the farm operations to the labors and others helping them in controlling these operations which the lime growers used to learn from the extension personnel resulting increasing in their supervision ability.

\section{Budgeting Ability of Lime Growers}

The data presented in Table 6 indicated that near about one half (54.00 per cent) of respondents were having medium budgeting ability. Whereas, 30.50 and 15.50 per cent respondents observed low to high level budgeting ability, respectively. Hence it can be concluded from the above information that majority (54.00 per cent) of lime growers had medium budgeting ability.

Table 6: Distribution of Lime Growers According to Their Budgeting Ability About Recommended Cultivation of Lime $\mathbf{N}=\mathbf{2 0 0}$

\begin{tabular}{|c|l|c|c|}
\hline S.No. & \multicolumn{1}{|c|}{ Category } & Frequency & Percent \\
\hline 1. & Low (Below 3.31 score) & 61 & 30.50 \\
\hline 2. & Medium (from 3.31 to 7.47 score) & 108 & 54.00 \\
\hline 3. & High (Above 7.47 score) & 31 & 15.50 \\
\hline & Total & $\mathbf{2 0 0}$ & $\mathbf{1 0 0}$ \\
\hline & Mean = 5.39 score & \multicolumn{2}{|c|}{ S.D. $=\mathbf{2 . 8 8}$ score } \\
\hline
\end{tabular}

This might be due the reason that the lime growers of the study area used to make the budget of their farm themselves which depended on the available money and credit. The lime growers of the study area had medium borrowing ability from relative bank etc., which might have resulted in their medium budgeting ability. 


\section{Coordinating Ability of Lime Growers}

The data related to coordinating ability of lime growers has been presented in Table 7 as follows:

Table 7: Distribution of Lime Growers According to Their Coordinating Ability About Recommended Cultivation of Lime $\mathbf{N}=200$

\begin{tabular}{|c|l|c|c|}
\hline S.No. & \multicolumn{1}{|c|}{ Category } & Frequency & Percent \\
\hline 1. & Low (Below 2.97 score) & 26 & 13.00 \\
\hline 2. & Medium (from 2.97 to 6.03 score) & 144 & 72.00 \\
\hline 3. & High (Above 6.03 score) & 30 & 15.00 \\
\hline & Total & $\mathbf{2 0 0}$ & $\mathbf{1 0 0}$ \\
\hline & Mean =4.50 score & \multicolumn{2}{|c|}{ S.D. $=\mathbf{1 . 5 3}$ score } \\
\hline
\end{tabular}

The data presented in table 7 revealed that 72.00 per cent of the respondents had medium level coordinating the activities followed by low 13.00 per cent and high 15.00 per cent coordinating the activities on their orchards.

It can be summarized that majority of lime growers possessed medium level coordinating ability. The probable reason for this finding might be that the lime orchard was laid on an average in 0.2 to 0.5 hectare land in the study area on which the lime growers tried to coordinate the activities of labors, family members and contractors etc. which might have increased his coordinating ability.

\section{Controlling Ability of Lime Growers}

It can be observed from the Table 8 that more than one-third (44.50 per cent) of the respondents had medium controlling ability while 40.00 per cent respondents had low controlling ability. The remaining 10.50 per cent possessed high controlling ability. Hence, it can be concluded that the controlling ability of lime growers about recommended cultivation was found medium to low category.

\section{Table 8: Distribution of Lime Growers According to Their Controlling Ability} About Recommended Cultivation of Lime $\mathbf{N}=200$

\begin{tabular}{|c|l|c|c|}
\hline S.No. & \multicolumn{1}{|c|}{ Category } & Frequency & Percent \\
\hline 1. & Low (Below 2.49 score) & 80 & 40.00 \\
\hline 2. & Medium (from 2.49 to 5.19 score) & 99 & 49.50 \\
\hline 3. & High (Above 5.19 score) & 21 & 10.50 \\
\hline & Total & $\mathbf{2 0 0}$ & $\mathbf{1 0 0}$ \\
\hline & Mean = 3.84score & \multicolumn{2}{|c|}{ S.D.=1.35 score } \\
\hline
\end{tabular}

This might be due to the reasons that (40.50 per cent) of the lime growers were educated upto primary level education, which played an important role in controlling the activities of farm labours, contactors etc. resulting in their medium controlling ability.

\section{Communication ability of Lime Growers}

It can be observed from the Table 9 that majority of the respondents ( 65.50 per cent) had medium communication ability while, 27.00 per cent respondents had low communication ability, and the remaining 7.50 per cent respondents possessed high communication ability. Hence, it can be concluded that communication ability of lime growers about recommended cultivation was found medium to low category. 
Table 9: Distribution of Lime Growers According to Their Communication Ability About Recommended Cultivation of Lime $\mathbf{N}=\mathbf{2 0 0}$

\begin{tabular}{|c|l|c|c|}
\hline S.No. & \multicolumn{1}{|c|}{ Category } & Frequency & Percent \\
\hline 1. & Low (below 2.78 score) & 54 & 27.00 \\
\hline 2. & Medium (from 2.78 to 5.24 score) & 131 & 65.50 \\
\hline 3. & High (above 5.24 score) & 15 & 7.50 \\
\hline & Total & $\mathbf{2 0 0}$ & $\mathbf{1 0 0}$ \\
\hline & Mean = 4.01score & \multicolumn{2}{|c|}{ S.D.=1.23 score } \\
\hline
\end{tabular}

This might be due to the reasons that the personal localite and cosmopolite sources of information like friends, neighbours, relatives and extension personnel had not been frequently used by the lime growers due to non-availability of such organizations / institutions in some area under study, which might have resulted in their medium communication ability.

\section{Decision Making Ability of Lime Growers}

It can be observed from the Table 10 that majority of the respondents $(75.50$ per cent $)$ had medium level of decision making ability, while 17.50 per cent of respondents had high level decision making ability, remaining 2.0 per cent respondents possessed low level ability, thus, decision making ability was predominantly medium to high. Hence, it can be concluded that the decision making ability of lime growers about recommended cultivation of lime was of medium to high category.

Table 10: Distribution of Lime Growers According to Their Decision Making Ability about Recommended Cultivation of Lime N = 200

\begin{tabular}{|c|l|c|c|}
\hline S. No. & \multicolumn{1}{|c|}{ Category } & Frequency & Percent \\
\hline 1. & Low (below 2.28 score) & 14 & 7.00 \\
\hline 2. & Medium (from 2.28 to 6.30 score) & 151 & 75.50 \\
\hline 3. & High (above 6.30 score) & 35 & 17.50 \\
\hline & Total & $\mathbf{2 0 0}$ & $\mathbf{1 0 0}$ \\
\hline & Mean =4.29score & S.D. $=\mathbf{2 . 0 1}$ score \\
\hline
\end{tabular}

This might be due to the reason that the lime growers used to make their decision on their own or with the help of family members or extension personnel, resulting in their medium decision making ability.

\section{Human Relationship Ability of Lime Growers}

It can be observed that from the Table 11 that 44.50 per cent of the respondents had medium human relationship. While, 37.50 per cent of the respondents had low human relationship ability, the remaining 18.00 per cent respondents possessed high human relationship

Table 11: Distribution of Lime Growers According to Their Human Relationship Ability about Recommended Cultivation of Lime $\mathbf{N}=\mathbf{2 0 0}$

\begin{tabular}{|c|l|c|c|}
\hline S. No. & \multicolumn{1}{|c|}{ Category } & Frequency & Percent \\
\hline 1. & Low (below 2.55 score) & 75 & 37.50 \\
\hline 2. & Medium (from 2.55 to 7.57 score) & 89 & 44.50 \\
\hline 3. & High (above 7.57 score) & 36 & 18.00 \\
\hline & Total & $\mathbf{2 0 0}$ & $\mathbf{1 0 0}$ \\
\hline & Mean = 5.06score & \multicolumn{2}{|c|}{ S.D. $=\mathbf{2 . 5 1}$ score } \\
\hline
\end{tabular}

This might be due to that the lime grower tries to make human relationship with the farm laborers and contractors etc., to the extent, which does not harm his farm operations. Sometimes due to human relationship the farmer suffers 
hence, the lime growers do not show human relationship which resulted in their medium ability of making human relationship.

\section{Relative Importance of Different Indicators of the Management Ability of Lime Growers}

In order to know the relative importance of different indicators of the management ability of lime growers, the mean percent score (MPS) of each of the main indicators were calculated and ranks were assigned according and presented in table 12.

Table 12: Relative Importance of Different Indicators of the Managerial Ability of Lime Growers N= 200 (Multiple Response)

\begin{tabular}{|c|l|c|c|}
\hline S. No. & \multicolumn{1}{|c|}{ Practice } & Mean Percent Score & Rank \\
\hline 1. & Knowledge & 62.13 & V \\
\hline 2. & Planning & 64.54 & IV \\
\hline 3. & Organizing the activities & 68.30 & III \\
\hline 4. & Supervising & 69.42 & II \\
\hline 5. & Budgeting & 56.45 & VII \\
\hline 6. & Coordinating lime activities & 52.83 & VIII \\
\hline 7. & Communication & 70.50 & I \\
\hline 8. & Controlling lime activities & 57.43 & VI \\
\hline 9. & Decision making & 44.95 & IX \\
\hline 10. & Human relationship & 44.00 & X \\
\hline
\end{tabular}

From the Table 12, it can be observed that the highest mean per cent score was obtained by communication (70.50 MPS) and was placed at first rank this followed by supervising (69.42 MPS) organizing the activities (68.30 MPS), planning (64.54 MPS and knowledge (62.13 MPS), which were placed at second, third, fourth and fifth ranks, respectively, whereas, the managerial ability indicator like controlling the activities (57.43 MPS), budgeting (56.45 MPS), coordinating the activities (52.83 MPS) and decision making (44.95 MPS) were placed at sixth, seventh, eight and ninth ranks, respectively. The lowest mean per cent score was obtained by human relationship (44.00 MPS) and was placed at last rank.

Hence, it can be concluded that the indicators like communication, supervising, organizing the activities, planning and knowledge played a highly important role in the ability of the lime growers whereas lime growers like controlling the activities, budgeting, coordinating, decision making and human relationship played medium role in their managerial ability of lime growers.

The findings of this kind might be due to the reason that better communication obtained current and profitable information about modern technology that kept the farmers updated about scientific cultivation. The ability to communicate effectively with others is a management skill. It helps the farmers' to receive and disseminate profitable information relating to farmers enterprise. Communication skill also enables the farmers to keep in contact with the agricultural support system. Communication includes an effective and proper selection of massage, which is the means of achieving effective managerial ability.

The supervision ability also plays important role in accessing the farm operation to the labourer and others helping them in controlling these operations, it also included the surveillances against possible damage in lime orchards. The organizing is a process of identifying and grouping the work to be performed. These may be the reasons for obtaining the higher ranking to these indicators by the lime growers. The planning helps the farmer in proper allocation of resources and better organization of the goals. Adequate knowledge regarding recommended cultivation of lime practices is the 
prime requirement. Knowledge about current technology is essential to maximize return from an enterprise. It is a saying that education is the panacea for the life and knowledge is the determinant factor for the education.

The controlling is the process by which a farmer is concerned with maintaining various farm records i.e. expenditure income, labour payments and also engaged labour from various farms operation do in lime cultivation. Budgeting involves the allotment of the fund to the various activities and credit is an important part for production, which help in obtaining full benefits of the technology. Coordination is essential to the production inputs timely and in adequate quantities lime growers used these tools for wise counseling, monitoring, evolution and promoting teamwork. Rationality in decision-making helps the farmers to clearly setup the goals in farming. At the same time human relationship used for discharging their duties with a consideration of labour morale, treat them as social beings, which act positively on managerial ability.

\section{CONCLUSIONS}

- Majority of the lime growers possessed medium level of managerial ability.

- Among the different indicators of the managerial ability, majority of lime growers had medium level knowledge, medium planning ability, medium organizing ability, medium supervising ability, medium budgeting ability, medium coordinating ability, medium controlling ability, medium communication ability, medium decision making ability and medium human relationship making ability.

- Among the different indicators of the managerial ability of lime growers about recommended cultivation of lime, their communication, supervising, organizing, planning and knowledge contributed most in their managerial ability.

\section{REFERENCE}

1. Bhople, R.S. and Palaspagar, V.W. 1996. Appraisal of managerial ability of farm supervisor. PKV-Research Journal 20 (2) pp. 161-162.

2. Bora S.P. and Ray G.L. 1986. Management attributes of farmers as related to profitability in farming decision, 13 (2) : 86-93.

3. Bora, S.P. 1986. "Management attributes of farmers as related to profitability in farming. A study conducted in Chakdah Block of West Bengal" Unpublished Ph.D. Thesis, Department of Agricultural Extension, Bidhan Chandra Krishi Viswavidyalaya, West Bengal.

4. Jadav, N.B. 2004. Managerial ability of mango growers about scientific cultivation of mango orchard unpublished. Ph.D. Thesis, GAU, Junagarh.

5. Patel, A.A. and Patel, R.K. 2000. Growers managerial ability for plant protection measures in chilli crop. Gujarat Journal of Extension Education. X \& XI pp.1-4. 